\title{
Molecular characterization of hepatitis B virus in liver disease patients and asymptomatic carriers of the virus in Sudan
}

\author{
Mukhlid Yousif ${ }^{1}$, Hatim Mudawi ${ }^{2}$, Sahar Bakhiet ${ }^{3}$, Dieter Glebe ${ }^{4}$ and Anna Kramvis ${ }^{\text {1* }}$
}

\begin{abstract}
Background: Hepatitis B virus is hyperendemic in Sudan. Our aim was to molecularly characterize hepatitis B virus from Sudanese individuals, with and without liver disease, because genotypes play an important role in clinical manifestation and treatment management.

Methods: Ninety-nine patients - 30 asymptomatic, 42 cirrhotic, 15 with hepatocellular carcinoma, 7 with acute hepatitis and 5 with chronic hepatitis- were enrolled. Sequencing of surface and basic core promoter/precore regions and complete genome were performed.

Results: The mean \pm standard deviation, age was $45.7 \pm 14.8$ years and the male to female ratio 77:22. The median (interquartile range) of hepatitis B virus DNA and alanine aminotransferase levels were $2.8(2.2-4.2) \mathrm{log} \mathrm{IU} / \mathrm{ml}$ and 30 (19-49) IU/L, respectively. Using three genotyping methods, 81/99 (82\%) could be genotyped. Forty eight percent of the 99 patients were infected with genotype $D$ and 24\% with genotype E, 2\% with putative D/E recombinants and 7\% with genotype A. Patients infected with genotype $E$ had higher frequency of hepatitis B e antigen-positivity and higher viral loads compared to patients infected with genotype D. Basic core promoter/precore region mutations, including the G1896A in 37\% of HBeAg-negative individuals, could account for hepatitis B e antigen-negativity. Pre-S deletion mutants were found in genotypes $D$ and $E$. Three isolates had the vaccine escape mutant sM133T.

Conclusion: Sudanese hepatitis B virus carriers were mainly infected with genotypes D or E, with patients infected with genotype $\mathrm{E}$ having higher HBeAg-positivity and higher viral loads. This is the first study to molecularly characterize hepatitis B virus from liver disease patients in Sudan.
\end{abstract}

Keywords: Bioinformatics, Genotype, Serotype, Sudan, Subgenotype, Africa, Phylogenetics

\section{Background}

Hepatitis B virus (HBV), the prototype member of the family Hepadnaviridae is responsible for chronic infection of more than 240 million people worldwide [1], of which 65 million reside in Africa [2].

Sudan is an African country with high HBV seroprevalence of greater than $8 \%$ HBsAg-positivity, ranging from $6.8 \%$ in central Sudan to $26 \%$ in southern Sudan [3-5]. HBV infection occurs in early childhood in southern Sudan, with the infection increasing with age in northern Sudan $[3,6]$. HBV was shown to cause $22 \%$ of fulminant

\footnotetext{
*Correspondence: Anna.Kramvis@wits.ac.za

${ }^{1}$ Hepatitis Virus Diversity Research Programme, Department of Internal Medicine, Faculty of Health Sciences, University of Witwatersrand, 7 York Road, Parktown, Johannesburg 2193, South Africa

Full list of author information is available at the end of the article
}

hepatitis cases in Sudan [7] and 18.5\% of Sudanese blood donors were exposed to the virus and $4 \%$ were infected at the time of donation [8]. Nine genotypes of HBV, A-I, with a distinct geographic distribution have been recognized [9-11]. A tenth genotype, J, has been proposed but was found only in one person [12]. Genotype A, D and E circulate in Africa [2]. Genotype A prevails in southern, eastern and central Africa. Genotype D is the dominant genotype in northern Africa, whereas in western Africa genotype E predominates. Subgenotypes have also been identified within genotypes A and D $[9,10]$.

Considering Sudan's unique position and the flux of people across its borders, it is important that the HBV genotypes prevailing in this country are determined. In a single study, in Sudanese asymptomatic blood donors, it

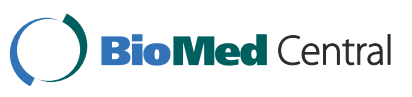


was found that $57.5 \%$ were infected with genotype E, $40.5 \%$ with genotype D and $2 \%$ with subgenotype A2 [8]. Moreover, a diversity of genotypes are distributed in neighbouring countries [2]: genotype D in Egypt to the north [13], genotype $\mathrm{E}$ in the Democratic Republic of Congo to the west [14] and genotype A in Kenya $[15,16]$ and Uganda [17] to the south. Knowledge of the genotypes prevailing in Sudanese, with and without liver disease, is important in treatment management, as well as disease prognosis because genotypes play a role in both of these aspects $[18,19]$.

The Regional committee for the World Health Organization (WHO) Eastern Mediterranean Region (EMR), to which Sudan belongs, urged member states to:

\section{"Improve the epidemiological surveillance systems, develop a hepatitis registry and implement serosurveys in order to produced reliable data to guide prevention and control measures and monitor impact of preventive strategies" [20].}

Thus our objective was to molecularly characterize HBV from HBsAg-positive persons with known clinical status.

\section{Methods}

\section{Serum samples}

A cross-sectional, laboratory based study was conducted. Ninety-nine sera were collected from HBsAg-positive patients referred to the hepatology and general medical clinics at IbnSina Hospital, Soba University Hospital and Khartoum Teaching Hospital in Khartoum State between August 2008 and March 2009. The clinical report forms (CRFs) were completed by qualified practitioners. Informed consent was obtained from each patient included in the study and the study protocol conforms to the ethical guidelines of the 1975 Declaration of Helsinki as reflected in a priori approval by the Human Ethics Committees of the University of the Witwatersrand and the University of Khartoum and the Ministry of Health of Sudan. Alanine amino transferase (ALT) levels were determined (reference range 5-40 IU/L) [21] and samples stored at $-20^{\circ} \mathrm{C}$. Chronic carriers were infected for longer than six months and were classified as asymptomatic carriers (ASCs) if they had normal ALT or chronic hepatitis $(\mathrm{CH})$ patients if they had abnormal ALT. Acute hepatitis (AH) cases were diagnosed based on clinical presentation (symptoms and clinical presence of jaundice) plus high ALT and the presence of hepatitis B core IgM antibody (HBcAbIgM). Clinical and ultrasonographic evidence were used to diagnose cirrhotic (CR) and hepatocellular carcinoma (HCC) cases.

\section{HBV serology}

HBsAg was assayed using Monolisa ${ }^{\mathrm{TM}}$ HBsAg ULTRA and HBeAg using Monolisa ${ }^{\mathrm{TM}}$ HBeAg-Ab PLUS kit (Bio-rad, Hercules, CA). Anti-HBe and anti-HBc antibodies were determined using $\mathrm{HBeAg} / \mathrm{Anti}-\mathrm{HBe}$ ELISA and Anti-HBc Total ELISA, respectively (DIAsource ImmunoAssays S.A, Nivelles, Belgium). Anti-HBc IgM was determined using the ARCHITECT ${ }^{\circledR}$ kit (Abbott Diagnostics, Wiesbaden, Germany).

\section{DNA extraction}

DNA was extracted from $200 \mu \mathrm{L}$ of serum using QIAamp DNA mini blood kit (QIAGEN GmbH, Germany), according to manufacturer's instructions, and eluted in $100 \mu \mathrm{L}$ of buffer.

\section{Real-time PCR quantification of HBV DNA}

PCR primers, HBV-Taq1 and HBV-Taq2 covering a region of the $\mathrm{S}$ gene (321 to 401 from the EcoRI site) with a FAM/TAMRA labelled TaqMan BS-1 probe [22] were used to quantify HBV DNA in an ABI 7500 Real Time PCR System (Applied Biosystems, Foster City, Ca, USA). A serial dilution of cloned plasmid DNA containing a single genome of $\mathrm{HBV}$ DNA, with concentrations ranging from $2 \times 10^{1}$ to $2 \times 10^{11} \mathrm{IU} / \mathrm{ml}$, was used as template to generate the standard curve. The second WHO International Standard for HBV Nucleic Acid Amplification Techniques (product code 97/750 National Institute for Biological Standards and Controls (NIBSC); Hertfordshire, UK), which has a final concentration of $10^{6} \mathrm{IU} / \mathrm{ml}$ was used as the internal standard. The standard curve, blank, positive and negative controls, and samples were all tested in duplicate. The measured $\mathrm{IU} / \mathrm{ml}$ for each reaction was calculated using the $\mathrm{Ct}$ (cycle threshold) value of each PCR interpolated against the linear regression of the standard curve. The lower detection limit of our assay is $\sim 20 \mathrm{IU} / \mathrm{ml}$. The conversion formula of IU $=$ copies $/ 4.7$ was used [23-25].

\section{Polymerase chain reaction (PCR) and restriction fragment polymorphism assay (RFLP)}

The basic core promoter/precore $(\mathrm{BCP} / \mathrm{PC})$ region and complete $\mathrm{S}$ open reading frame (ORF) were amplified in a MyCycler $^{\mathrm{TM}}$ thermocycler (Bio-Rad, Hercules, Ca, USA) using Promega Taq DNA polymerase (Promega, Madison, WI). The BCP/PC PCR was amplified using a slight modification of the method described by Takahashi and colleagues [26] primers 1606 (+) (1606-1625 from EcoRI site) and 1974 (-) (1974-1955 from EcoRI site) were used for the first round (denaturation $94^{\circ} \mathrm{C}$ for $1 \mathrm{~min}$, annealing $55^{\circ} \mathrm{C}$ for $1 \mathrm{~min}$, extension $72^{\circ} \mathrm{C}$ for $2 \mathrm{~min}, 40$ cycles) and 1653(+) (1653-1672 from EcoRI site) and 1959(-) (19591940 from EcoRI site) for the second round, with the identical cycling conditions as the first-round PCR [25,27]. A 
nested PCR was carried out to amplify the complete $S$ ORF : primers 2410(+) (2410-2439 from EcoRI site) and 1314(-) (1314-1291 from EcoRI site) were used for the first round (denaturation $94^{\circ} \mathrm{C}$ for $1 \mathrm{~min}$, annealing $66^{\circ} \mathrm{C}$ for $1 \mathrm{~min}$, extension $72^{\circ} \mathrm{C}$ for $3 \mathrm{~min}, 40$ cycles) and 2451 (+) (2451-2482 from EcoRI site) and 1280 (-) (1280-1254 from EcoRI site) for the second round (denaturation $94^{\circ} \mathrm{C}$ for $1 \mathrm{~min}$, annealing $65^{\circ} \mathrm{C}$ for $1 \mathrm{~min}$, extension $72^{\circ} \mathrm{C}$ for 3 min, 40 cycles) [27]. Another nested PCR reaction was carried out to amplify a short region of the S (459-710 from EcoRI site) to determine the genotype: primers 255 (+) (253-275 from EcoRI site) and 759 (-) (759-739 from EcoRI site) were used for the first round (denaturation $94^{\circ} \mathrm{C}$ for $30 \mathrm{sec}$, annealing $56^{\circ} \mathrm{C}$ for $40 \mathrm{sec}$, extension $72^{\circ} \mathrm{C}$ for 1 min, 40 cycles) and [459(+) (460-480 from EcoRI site)] and [710(-) (711-691 from EcoRI site)] for the second round (denaturation $94^{\circ} \mathrm{C}$ for $30 \mathrm{sec}$, annealing $56^{\circ} \mathrm{C}$ for $40 \mathrm{sec}$, extension $72^{\circ} \mathrm{C}$ for $50 \mathrm{sec}, 40$ cycles) [28]. When the complete S ORF and the short $\mathrm{S}$ could not be amplified, a RFLP assay was used to determine the genotype of the HBV isolates. Primers P7 (256-278 from EcoRI site) and P8 (796-776 from EcoRI site) were used to amplify nucleotides 256-796 of the $S$ region. The amplicon was then cleaved using restriction enzymes HinfI and Tsp509I, in separate reactions, to give the characteristic RFLP patterns for the different genotypes [29]. The complete genome was amplified using a single amplification method with primers P1 (1821-1841 from EcoRI site) and P2 (1825-1806 from EcoRI site), with modifications in the cycling conditions [30]. Initial denaturation at $98^{\circ} \mathrm{C}$ for $1 \mathrm{~min}, 80^{\circ} \mathrm{C}$ for $30 \mathrm{sec}$ followed by adding the polymerase mix, $98^{\circ} \mathrm{C}$ for $1 \mathrm{~min}$, then 35 cycles of: $98^{\circ} \mathrm{C}$ for $10 \mathrm{sec}, 57^{\circ} \mathrm{C}$ for $30 \mathrm{sec}$ and $72^{\circ} \mathrm{C}$ for $1 \mathrm{~min}$.

\section{Sequencing}

The BigDye Terminator v3.0 Cycle Sequencing Ready Reaction Kit (Applied Biosystems., Foster City, USA) was used and sequencing performed using the ABI 3130XL Genetic analyzer (Applied Biosystems, Foster City, CA). In addition to sequencing primers: 2497F (2497-2516), 3188F (3188-3206) and 591F (591-611) used previously [27,31], four new primers: 1069F (1069-1088) (5'- TGT ATT CAA TCT AAG CAG GC-3'), Post-Bgl III (20002017) (5'-CCG ATA CAG AGC TGA GGC-3'), 2022F (2022-2041) (5' -CCT TAG AGT CTC CTG AGC AT-3 '), 2480R (2461-2480) (5'-CAC CTT ATG AGT CCA AGG AA-3'), were used to sequence the complete genome. All positions are numbered from the EcoRI site of genotype A (AY233286). The three overlapping fragments of the complete $\mathrm{S}$, and the 7 fragments of the complete genome thus obtained, were assembled using the Fragment Merger Tool [32]. Sequences were deposited in GenBank, accession numbers KF170739-KF170812.

\section{Phylogenetic analysis}

Neighbour-joining using MEGA5 [33] or PHYLIP (Phylogeny inference package version 3.69) or DNADIST consecutively with NEIGHBOR were used to generate dendrograms [34].

\section{Analysis for intergenotypic recombination}

SimPlot 3.5.1@, an interactive 32-bit software program, that plots distances (or similarity) versus position [35] was used to show recombination in isolate SDAC031 [33].

\section{Results}

\section{HBV serology and viral loads}

Of the 99 patients, 77 were males and 22 were females. Mean age \pm standard deviation (SD) was [45.7 \pm 14.8$]$ years. All sera were $\mathrm{HBsAg-}$ and anti-HBc-positive; 12 were HBeAg-positive/anti-HBe-negative, 75 were $\mathrm{HBeAg-}$ negative/anti-HBe-positive, and 12 had neither $\mathrm{HBeAg}$ nor anti-HBe. All patients were HBV DNA-positive, with a median (interquartile range) (IQR) viral load of [2.8 (2.2-4.2)] $\log$ IU/ml and ALT median (IQR) level was [30 (19-49)] IU/L (reference range 5-40 IU/L) [21].

\section{Clinical and demographic characteristics}

The 99 cases were classified into five clinical groups: HCC $(n=15), C R(n=42), \operatorname{ASCs}(n=30), A H(n=7)$ and $\mathrm{CH}(\mathrm{n}=5)$. The HCC patients were significantly older than patients in the other groups $(\mathrm{p}<0.05)$ and the AH patients were significantly younger $(\mathrm{p}<0.05)$. The ALT levels were the highest in the AH (p <0.05) (Table 1). The median viral load of HBeAg-positive patients [6.99 (5.63-7.57) $\log \mathrm{IU} / \mathrm{ml}]$ was significantly higher than in HBeAg-negative patients [2.55 (2.09-3.42) log IU/ml] $(\mathrm{p}<0.05)$. The viral loads and frequency of $\mathrm{HBeAg}-$ positivity did not differ between clinical groups.

\section{HBV genotyping and phylogenetic analysis}

In order to maximize the number of isolates genotyped, three methods were used sequencially (Figure 1).

$81 \mathrm{HBV}$ isolates were thus successfully genotyped

Firstly, 53 of 99 were genotyped using amplification and sequencing of the complete S (2848-835 from EcoRI), followed by phylogenetic analysis (Figure 2), secondly,17 of 46 were genotyped by amplification and sequencing of a short S fragment (520-704 from EcoRI), followed by phylogenetic analysis (trees not shown) and thirdly,11 of 29 by RFLP analysis.

The relatively longer amplicon of the $S$ region of 2.1 $\mathrm{kb}$ in length, compared to the shorter regions used for the short $\mathrm{S}$ and RFLP amplifications, meant that not all samples could be amplified in the longer region successfully. $18.2 \%$ (18/99) could not be genotyped using any of the three methods. No sequences could be obtained for 10 of these isolates and for the remaining 8 only the 
Table 1 Demographic and clinical characteristics of 99 patients

\begin{tabular}{|c|c|c|c|c|c|}
\hline & \multicolumn{5}{|c|}{ Clinical status } \\
\hline & HCC (15) & ASC (30) & CR (42) & $\mathrm{AH}(7)$ & $\mathrm{CH}(5)$ \\
\hline Male: Female & 13:02 & $22: 08$ & $37: 05: 00$ & 02:05 & 03:02 \\
\hline Age mean \pm SD & $57.3 \pm 13.8^{\mathrm{a}}$ & $42.8 \pm 15.1$ & $46.5 \pm 12.9$ & $32.1 \pm 12.4^{\mathrm{a}}$ & $37.6 \pm 41.0$ \\
\hline ALT median IU/L (IQR) & $40(24-50)$ & $22(18-33)$ & $27(18-45)$ & $461(312-834)^{a}$ & $38(29-47)$ \\
\hline HBeAg positive (\%) & $2(13.3)$ & $2(6.7)$ & $7(16.7)$ & $1(14.3)$ & 0 \\
\hline Log viral loads & 3.8 & 2.5 & 2.8 & 3 & 2.1 \\
\hline $\mathrm{IU} / \mathrm{ml}$ median (IQR) & $(2.4-4.7)$ & $(2.2-3.3)$ & $(2.2-5.3)$ & $(2.2-3.8)$ & $(2.0-3.6)$ \\
\hline
\end{tabular}

HCC Hepatocellular carcinoma, ASC Asymptomatic carriers, CR Cirrhosis, AH Acute hepatitis, CH Chronic hepatitis.

${ }^{\text {a }}$ Significant difference with other groups.

$\mathrm{BCP} / \mathrm{PC}$ region was sequenced, which is not sufficient to differentiate between genotypes $\mathrm{D}$ and $\mathrm{E}$.

The genotype distribution in the 81 samples was 59\% genotype D: $30 \%$ genotype E: $8.5 \%$ genotype A: $2.5 \%$ putative $\mathrm{D} / \mathrm{E}$ recombinant. If we include the 18 samples that could not be genotyped, $48.5 \%$ (48/99) were infected with genotype D, 24.2\% (24/99) with genotype E, 7.1\% (7/99) with genotype A and 2\% (2/99) were infected with a putative $\mathrm{D} / \mathrm{E}$ recombinant.
Phylogenetic analysis of the complete $\mathrm{S}$ region allowed for further classification into subgenotypes (Figure 2). Based on the recently suggested classification system [33], 23 of 31 genotype D isolates belonged to subgenotype D1 (74\%), 3 to D2 (10\%), 1 to D3 (3\%) and 4 to D6 (13\%). One genotype A isolate belonged to subgenotype A1 (Figure 2).

The complete genome of four isolates was amplified, two (SDAC024 and SDAC031) belonged to genotype D and two (SDAC047 and SDAC125) to genotype E.

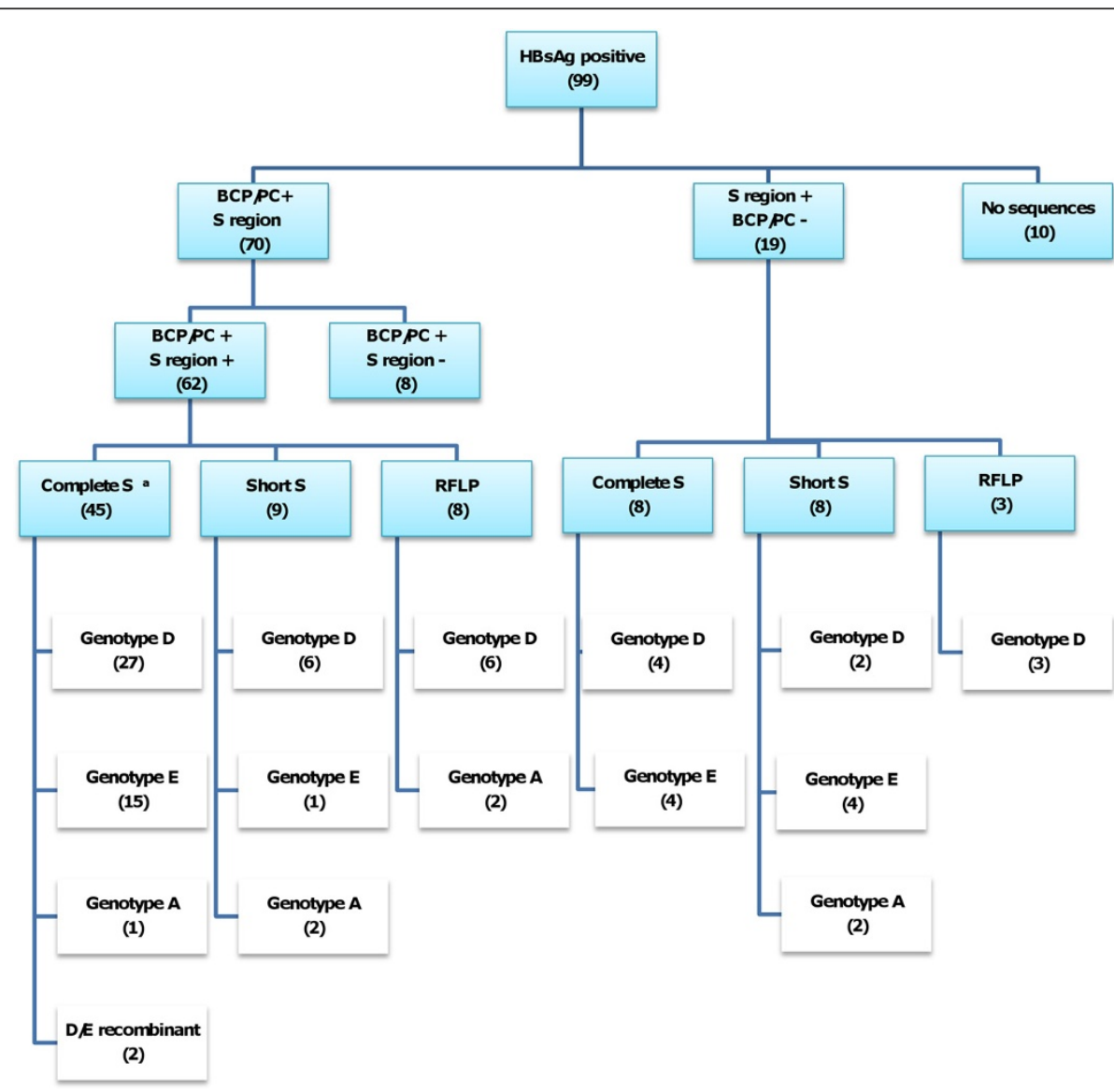

Figure 1 Algorithm summarizing protocol and results of the molecular characterization of BCP/PC region and genotyping of HBV. a Three isolates showed genotype $\mathrm{D}$ based on $\mathrm{S}$ region and genotype $\mathrm{A}$ based on BCP/PC region. 


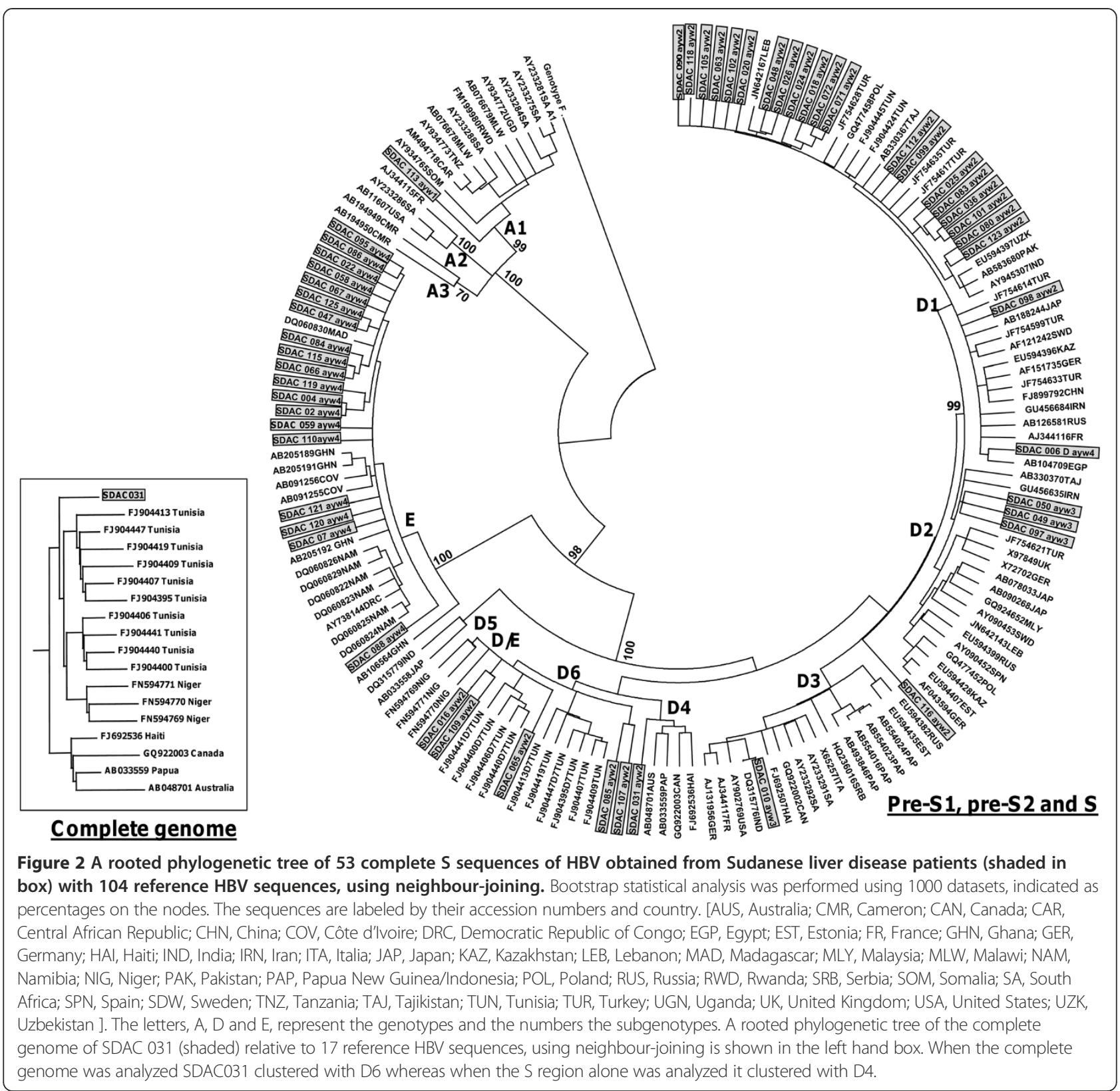

Although the genotypes determined using the complete genome agreed with that determined using the S ORF, there was a discrepancy in the subgenotype classification of SDAC031. Using phylogenetic analysis of the complete $\mathrm{S}$, it clustered as an outlier of subgenotype D4, whereas following complete genome phylogenetic analysis it clustered with D6 (Figure 2). Simplot analysis showed SDAC031 to be a recombinant of D6 and D4. By mapping the informative sites, we estimated the transition positions between D6 and D4 (Figure 3). The genotype E isolates (SDAC047 and SDAC125) clustered together when the complete $\mathrm{S}$ was compared, whereas they separated into different clades in the complete genome analysis (data not shown).
Although the majority of subgenotype D isolates showed the respective distinct subgenotype amino acids signatures [33], there were exceptions. SDAC031 (D6) showed preS2I42T, spV59F and rtT237P. SDAC085 (D6) had spV59S. SDAC107 (D6) had preS2I42T and rtT237P. All 17 genotype $\mathrm{E}$ isolates had genotype $\mathrm{E}$ signature amino acid motifs.

\section{Comparison of patients infected with genotypes $D$ and $E$}

Because the majority were infected with either genotype D or E, further analyses compared the patients' clinical and virological features infected with these genotypes. No significant difference was observed in gender, age, ALT and 


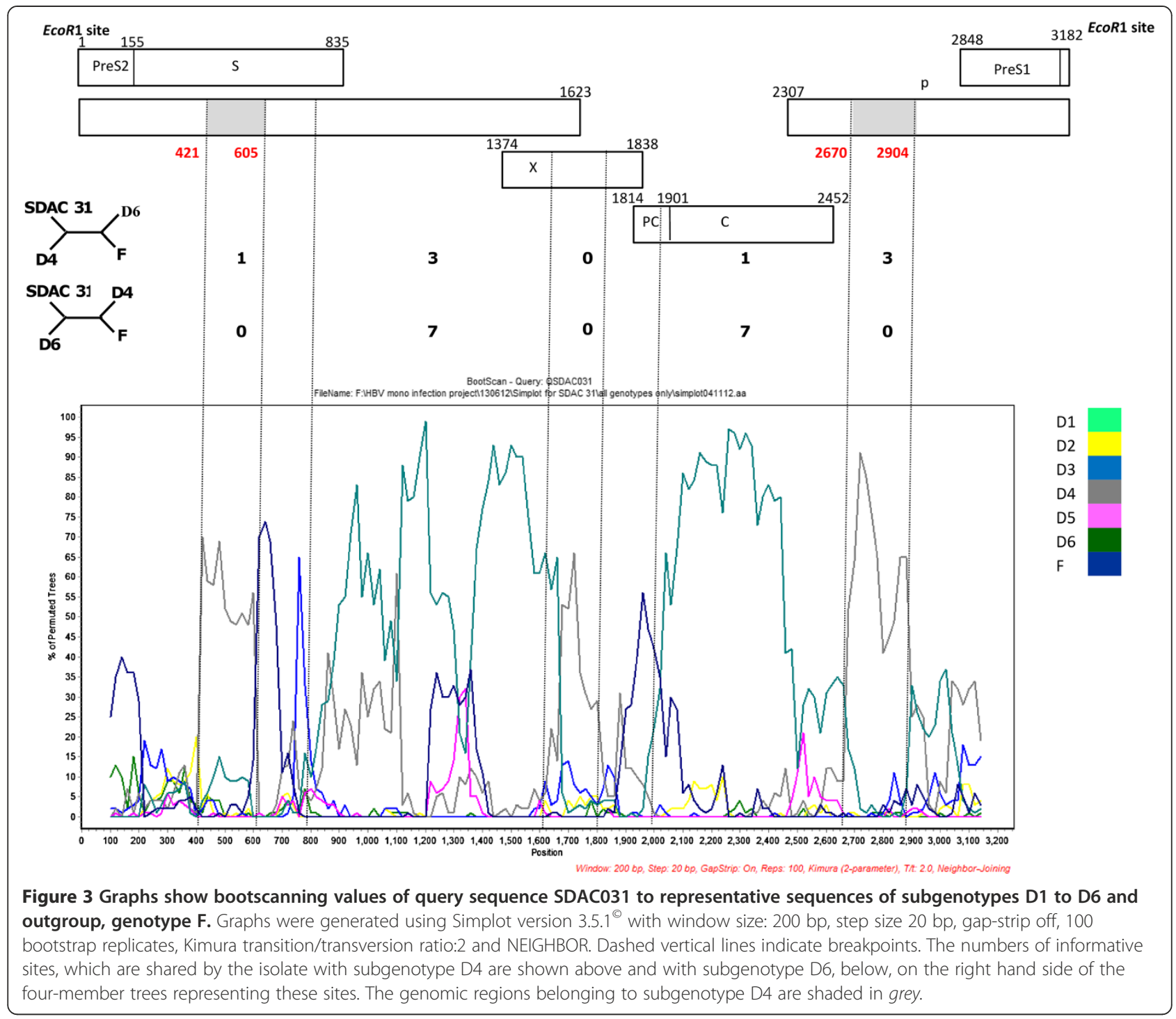

clinical groups of patients infected with either genotype. Patients infected with genotype E, showed a significantly higher frequency of HBeAg-positivity compared to patients infected with genotype D $(\mathrm{p}<0.05)$ and HBV DNA levels in patients infected with genotype $\mathrm{E}$ were significantly higher $(\mathrm{p}<0.05)$ (Table 2$)$.

\section{Molecular characterization of $\mathrm{HBV}$ isolates}

Analysis of basic core promoter/precore (BCP/PC) region

Of the 70 isolates amplified and sequenced in the $\mathrm{BCP} / \mathrm{PC}$ region, 62 amplfied in the $\mathrm{S}$ region and thus had genotype assignments. 57 isolates belonged to either genotype D or $\mathrm{E}$, and 5 to genotype A. Seven of 8 genotype D or E isolates

Table 2 Clinical and demographic characteristics of 81 patients, for which HBV was genotyped

\begin{tabular}{|c|c|c|c|c|c|c|c|c|c|c|}
\hline & \multirow{2}{*}{\multicolumn{5}{|c|}{ Clinical status }} & \multirow{2}{*}{\multicolumn{2}{|c|}{$\begin{array}{c}\text { Demographic } \\
\text { characteristics }\end{array}$}} & \multirow{2}{*}{\multicolumn{3}{|c|}{$\frac{\text { Biochemical and virological }}{\text { characteristics }}$}} \\
\hline & & & & & & & & & & \\
\hline & HCC (13) & ASC (24) & CR (33) & $\mathrm{AH}(7)$ & $\mathrm{CH}(4)$ & Male: Female & $\begin{array}{c}\text { Age } \\
\text { mean } \pm S D\end{array}$ & $\begin{array}{l}\text { ALT median } \\
\text { IU/L (IQR) }\end{array}$ & $\begin{array}{c}\mathrm{HBeAg} \\
\text { positive (\%) }\end{array}$ & $\begin{array}{c}\text { Viral loads log } \\
\text { median IU/ml (IQR) }\end{array}$ \\
\hline Genotype D (\%) & $4(30.7)$ & $14(58.3)$ & $23(69.7)$ & $4(57.1)$ & $3(75)$ & $38: 10$ & $44.6 \pm 15.1$ & $29(19-57)$ & $4(8.3)$ & $2.8(2.0-3.9)$ \\
\hline Genotype E (\%) & $6(46.2)$ & $6(25)$ & $8(24.3)$ & $3(42.9)$ & $1(25)$ & $17: 07$ & $49.3 \pm 14.3$ & $29(18-65)$ & $7(29.2)^{a}$ & $4(2.6-5.7)^{a}$ \\
\hline Genotype D/E (\%) & $1(7.7)$ & 0 & $1(3)$ & 0 & 0 & $2: 0$ & $56.5 \pm 7.0$ & NA & 0 & $2.4(2.3-2.41)$ \\
\hline Genotype A (\%) & $2(15.4)$ & $4(16.7)$ & 1(3) & 0 & 0 & $5: 2$ & $38.14 \pm 14.51$ & $33(28-54)$ & $1(14.3)$ & $2.6(2.3-3.9)$ \\
\hline
\end{tabular}

$H C C$, Hepatocellular carcinoma; ASC, Asymptomatic carriers; $C R$, Cirrhosis; $A H$, Acute hepatitis, $\mathrm{CH}$, Chronic hepatitis.

${ }^{a}$ Significant difference between patients infected with genotype $D$ or $E$. 
from $\mathrm{HBeAg}$-positive patients had wild-type $\mathrm{BCP} / \mathrm{PC}$, and one (SDAC118) had G1764T. The mutations found in genotype $\mathrm{D}$ or $\mathrm{E}$ isolates from $\mathrm{HBeAg}$-negative individuals are shown in Figure 4: 15/49 genotype D or E isolates from HBeAg-negative sera, had wild-type $\mathrm{BCP} / \mathrm{PC}$ region. In 22/49 HBeAg-negative sera, the absence of HBeAg was as a result of missense mutations affecting the translation of the HBeAg precursor: 18 had the classical stop codon mutation G1896A ( $\mathrm{p}<0.05$, when comparing isolates from HBeAg-negative and -positive sera) and 4 had initiation codon mutations, 2 A1814T and 2 T1815C. A1762T/ G1764A was found in 11 G1896A mutants and in one T1815C mutant. Six isolates from HBeAg-negative sera had A1762T/G1764A alone. The Kozak sequence was GCAC at 1809-1812 in 45 isolates, GTAC in isolate SDAC 121 and TCAT with 1858C and 1888A in isolates SDAC018, SDAC090 and SDAC091. SDAC050 had 1858C with 1888A alone.

Although generally the $\mathrm{BCP} / \mathrm{PC}$ region cannot be used to determine specific genotypes, genotype $\mathrm{A}$ and its subgenotypes can be differentiated from genotypes D or $E$ because of specific sequence characteristics. One genotype A isolate from a $\mathrm{HBeAg-positive} \mathrm{patient,}$ (SDAC108) had A1762T/G1764A. From the BCP/PC sequences it was deduced that this isolate belonged to subgenotype A2, because it had GCAC at 1809-1812, 1858C and 1888G. The other four genotype A isolates were from HBeAg-negative individuals. These isolates, SDAC062, SDAC073 SDAC100 and SDAC113, belonged to subgenotype A1 because they had TCAT at 1809$1812,1858 \mathrm{C}$ and 1888A. One isolate had wild-type BCP/ PC region, two had A1762T/G1764A, one with G1862T and the fourth isolate had G1862T alone. No significant association was found between the $\mathrm{BCP} / \mathrm{PC}$ mutations and genotypes or clinical groups.
Analysis of the pre-S1, pre-S2, Surface and Polymerase regions The complete $\mathrm{S}$ region was sequenced for 53 isolates and pre-S mutations were detected in 14 (26\%). Four mutational patterns were identified: pre-S1 deletions $(2 / 14$; $14 \%)$, pre-S2 start codon mutation $(4 / 14 ; 29 \%)$, pre-S2 start codon mutation with pre-S2 deletion $(1 / 14 ; 7 \%)$ and pre-S2 deletion alone $(7 / 14 ; 50 \%)$ (Table 3). Transcription regulatory box domain substitutions [CCAAT $\rightarrow$ CTAAT] (803-807 from EcoRI site), were found in two isolates (SDAC095 genotype E and SDAC098 genotype D). Three cis-acting elements mutations were found: C1092T in the Enhancer I in one isolate, C1155T in the Enhancer I in 6 isolates and T3109G S2 promoter in 2 isolates. PreS2F22L was found in 6 genotype $\mathrm{E}$ and three genotype D isolates. The vaccine escape mutation, sM133T, was observed in genotype E isolates, SDAC022, SDAC067 and SDAC088. In the reverse transcriptase domain of the polymerase, the following mutations were detected: rtA194T in SDAC049 (genotype D), rtV207M in SDAC020 (genotype D), rtS213T in SDAC063 and SDAC098 (genotype D), SDAC002, SDAC121 and SDAC004 (genotype E), rtV214A in SDAC059 (genotype E) and rtS215Q in SDAC049 and SDAC090 (genotype D).

\section{Discussion}

In Sudan, where HBV is hyperendemic, little is known about the genotypes and mutants of HBV in liver disease patients. Thus HBV, from 99 patients, belonging to five clinical groups, were studied. Of the 81 samples that were successfully genotyped, close to $60 \%$ belonged to genotype D whereas the opposite was true in Sudanese blood donors, where genotype E prevailed (57\%) [8]. HCC patients in this study, who were infected with either genotype D or E, were significantly older than ASC, $\mathrm{CH}, \mathrm{AH}, \mathrm{CR}$ patients, with the AH patients being significantly younger (Table 1 ).

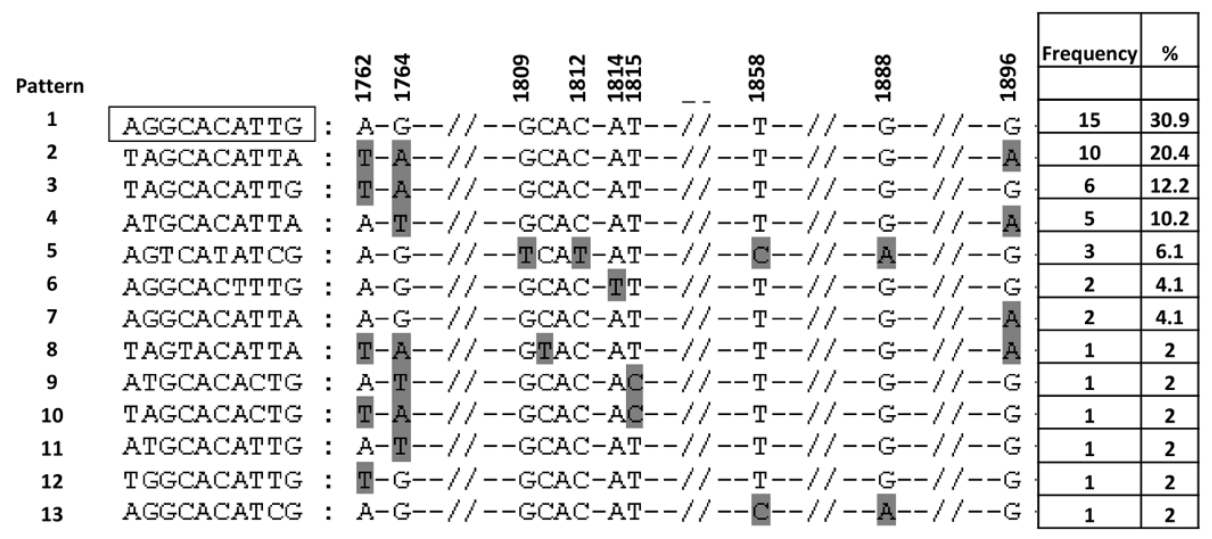

Figure 4 Mutation distribution in the basic core promoter/precore region, at 11 loci of interest $(1762,1764,1809-1812,1814,1815$, 1858, 1888 and 1896), of 49 genotype D or E HBV isolates from HBeAg-negative patients. Boxed motif represents the wild- type of genotypes D or E. Data were obtained using the Mutation Reporter Tool [36]. Mutations are shaded in grey. The frequency of the mutational patterns did not differ between genotype $\mathrm{D}$ and $\mathrm{E}$. 
Table 3 Pre-S region mutations and deletions

\begin{tabular}{|c|c|c|c|c|c|c|c|c|c|}
\hline \multirow[b]{3}{*}{ ID } & \multirow[t]{3}{*}{ Clinical group } & \multirow[t]{3}{*}{ Genotype } & \multirow[t]{3}{*}{ Pre-S2 S tart codon } & \multicolumn{6}{|r|}{ Deletions } \\
\hline & & & & \multirow[t]{2}{*}{ Region } & \multicolumn{2}{|c|}{ Nucleotides } & \multicolumn{2}{|c|}{ Amino acids } & \multirow[t]{2}{*}{ Region and functions affected } \\
\hline & & & & & Size & Position & Size & position & \\
\hline SDAC024 & $C R$ & $\mathrm{D}$ & ATG & Pre-S2 & 21 & $35-55^{\mathrm{a}}$ & 7 & $16-22^{a}$ & \\
\hline SDAC048 & $C R$ & $\mathrm{D}$ & ATG & Pre-S1 & 72 & 2998-3069 & 24 & $51-74$ & S promoter, Transactivator domain \\
\hline SDAC083 & $C R$ & $\mathrm{D}$ & ATG & Pre-S2 & 21 & $35-55$ & 7 & $16-22$ & \\
\hline SDAC097 & $C R$ & D & $G_{T} G^{b}$ & Pre-S 2 & 9 & $45-53$ & 3 & $19-21$ & \\
\hline SDAC098 & $\mathrm{CH}$ & $\mathrm{D}$ & ATG & Pre-S1 & 18 & $3129-3146$ & 6 & $94-99$ & $\begin{array}{l}\text { Hsc70 binding site, CCAAT binding factor (CBF) } \\
\text { binding site, Cytosolic anchorage determinant (CAD) }\end{array}$ \\
\hline SDAC112 & ASC & $\mathrm{D}$ & ATG & Pre-S2 & 6 & $49-54$ & 2 & $20-21$ & \\
\hline SDAC118 & $C R$ & $\mathrm{D}$ & ATG & Pre-S2 & 54 & $4-57$ & 18 & 5 to 22 & pHSA binding site, Viral secretion \\
\hline SDAC107 & $C R$ & $\mathrm{D}$ & ATA & - & - & - & - & - & - \\
\hline SDAC090 & $C R$ & D & ATA & - & - & - & - & - & - \\
\hline SDAC058 & $C R$ & $E$ & ATG & Pre-S2 & 9 & $58-66^{c}$ & 3 & $20-22^{c}$ & Transactivator domain \\
\hline SDAC059 & $\mathrm{HCC}$ & $E$ & GTG & Pre-S2 & 12 & $52-63$ & 4 & $18-21$ & Transactivator domain \\
\hline SDAC088 & $\mathrm{HCC}$ & $E$ & ATG & Pre-S2 & 12 & $52-63$ & 4 & $18-21$ & Transactivator domain \\
\hline SDAC095 & $\mathrm{HCC}$ & $E$ & ATG & Pre-S2 & 15 & $52-66$ & 5 & $18-22$ & Transactivator domain \\
\hline SDAC067 & ASC & $E$ & GTG & - & - & - & - & - & - \\
\hline SDAC113 & ASC & $A$ & $A C A$ & - & - & - & - & - & - \\
\hline
\end{tabular}

${ }^{a}$ nucleotide or amino acid position relative to genotype D (GU456684).

b mutant pre-S2 start codon italicized.

c nucleotide or amino acid position relative to genotype $E$ (AB205191).

This differs from HCC patients, infected with genotype A, who develop cancer at a significantly younger age [28]. In agreement with others [37,38], the HCC group had the highest median viral load. High viral loads have been implicated as a risk factor for HCC development [39].

In agreement with the study in Sudanese blood donors [8], the predominant subgenotype of D was D1. Furthermore, following phylogenetic analysis of the complete $\mathrm{S}$ region, two isolates, which lacked the 33 nucleotide deletion, characteristic of genotype $\mathrm{D}$, were genotype $\mathrm{D} / \mathrm{E}$ recombinants $[8,33,40]$. Following phylogenetic analysis of the complete $\mathrm{S}$, one isolate belonged to subgenotype $\mathrm{A} 1$, and from the $\mathrm{BCP} / \mathrm{PC}$ sequence, a further four were deduced to belong to subgenotype A1 [41]. This is the first time that subgenotype A1 has been identified in Sudan whereas a previously sequenced genotype A isolate from Sudan belonged to A2 [8]. Subgenotype A1 circulates in southern and eastern Africa and Southern Asia and A2 is found in Northern and Central Europe and North America [42].

Discrepant results were obtained in the subgenotype assignment of SDAC031 when the complete S and complete genome were analyzed. The complete $\mathrm{S}$ clustered as an outlier of D4 whereas the complete genome clustered with D6. D4 and D6 are phylogenetically closely related (Figure 2). Further analysis using Simplot, showed that it was a D6/D4 recombinant (Figure 3) and the majority of signature amino acids were of D6, with the exception of a number of amino acids, which were of D4 [33]. Geographically, D6 is distributed in theMaghreb and Madagascar, whereas D4 in the Americas and Australia. It is possible that D4 originated in Africa but has subsequently been replaced by other subgenotypes of $\mathrm{D}$ and the recombinant is a remnant of the original strain/s.

The HBV genotypes show a distinct geographical distribution in Africa, with genotype D predominating in the North, genotype E in the West and genotype A in the South-East [9]. This is the first study to describe the co-circulation of genotypes $\mathrm{D}$ and $\mathrm{E}$ in liver disease patients and to allow the comparison of patients infected with these two genotypes. In agreement with a study carried out in Sudanese blood donors [8], viral loads were significantly higher in genotype E-infected patients compared to genotype D-infected, with patients infected with genotype $\mathrm{E}$, showed a significantly higher frequency of HBeAg-positivity. The small size of HBeAg allows it to traverse the placenta and elicit $\mathrm{HBe} / \mathrm{HBcAg}$-specific $\mathrm{T}$ helper cell tolerance in utero [43]. Thus babies born to HBeAg-positive mothers have high chronicity rates than those born to HBeAg-negative mothers [43]. The high frequency of HBeAg-positivity in mothers infected with genotype $\mathrm{E}$, would lead to its vertical transmission and 
explain the high prevalence and geographical restriction of this genotype in Africa and to African emigrants to other regions [14]. The higher HBeAg-positivity seen in individuals infected with genotype $\mathrm{E}$, could confer tolerance and less serious clinical manifestations than genotype D, where HBeAg-positivity was lower. This could explain why genotype E prevails in the Sudanese blood donors [8], whereas genotype $\mathrm{D}$ prevailed in the liver disease patients in the present study.

The majority of the HBeAg-negativity was as a result of the classical G1896A, which abolishes HBeAg expression [44] and occurs in genotype D or E but not A because the encapsidation signal secondary structure precludes this mutation in genotype A $[45,46]$. Other mutations including transcriptional A1762T/G1764A and translation initiation mutations were responsible of HBeAg-negativity in a number of patients. Three isolates had TCAT instead of GCAC in the Kozak sequence preceding the precore initation codon and can affect $\mathrm{HBeAg}$ expression at the translational level [47]. This Kozak mutation occurred together with 1858C and 1888A (pattern 5, Figure 4), which are characteristics of subgenotype A1 [41]. One isolate has $1858 \mathrm{C}$ and 1888A alone. However, following phylogenetic analysis of the complete $\mathrm{S}$ region, these four isolates were found to belong to genotype $\mathrm{D}$. It is possible that these patients were co-infected with genotypes $\mathrm{D}$ and $\mathrm{A}$ or with $\mathrm{D} /$ A recombinants. These possibilities can only be discriminated by complete genome cloning and sequencing.

Four different pre-S mutational patterns were identified (Table 3). In genotype E, pre-S2 deletions were found mainly in HCC patients, whereas in genotype D, the deletion mutants were from non-HCC patients. However, the numbers were small to reach any firm conclusions. Pre-S deletion mutants were found in genotype $\mathrm{E}$ isolates from ASCs from Guinea [48] and Sudan [8]. Pre-S deletion/mutations affect the progression to serious liver disease in patients infected with either genotype B or C [49].

Six genotype $\mathrm{E}$ and three genotype $\mathrm{D}$ isolates had preS2F22L, which is a risk factor for HCC [50,51]. Interestingly, three genotype E isolates had the sM133T mutation, which could possibly compromise antibody neutralization and may represent potential vaccine escape mutants [52]. However, because these individuals were not vaccinated for $\mathrm{HBV}$, this mutation may have emerged as a result of host immune pressure. The reverse transcriptase mutations rtA194T, rtV207M, rtS213T, rtV214A and rtS215Q detected in the present study are neither primary resistance mutations, nor have they ever been seen in overt resistance during therapy [53]. When mutations rtA194T, rtV207M rtS213T rtV214A and rtQ215S were tested in our sensitive and reliable in vitro resistance test system, the mutants showed no resistance to lamivudine (LMV), entecavir
(ETV), adenofovir (ADF) and tenofovir (TDF). (Glebe et al., unpublished observations).

\section{Conclusion}

This is the first study to molecularly characterize HBV from Sudanese liver disease patients, who were predominantly infected with genotypes D and E, allowing comparison of the effect of these genotypes on clinical manifestation in the same ethnic group.

\section{Abbreviations}

AH: Acute hepatitis; ALT: Alanine amino transferase; ASC: Asymptomatic carriers; BCP/PC: Basic core promoter/precore; $\mathrm{CH}$ : Chronic hepatitis; CRF: clinical report form; DFG: Deutsche Forschungsgemeinschaft (German Research Foundation); DNA: Deoxyribonuclease; HBCAb: Hepatitis B core antibody; HBeAb: Hepatitis B e antibody; HBeAg: Hepatitis B e antigen; HBsAb: hepatitis B surface antibody; HBsAg: Hepatitis B surface antigen; HBV: hepatitis B virus; HCC: Hepatocellular carcinoma; IQR: Interquartile range; CR: cirrhosis; ORF: open reading frame; PCR: Polymerase chain reaction; RFLP: Restriction fragment polymorphism; rt: Reverse transcriptase; s: Surface; sp: Spacer; WHO: World Health Organization.

\section{Competing interests}

The authors declare that there are no competing interests.

\section{Authors' contributions}

Conceived the study: AK, DG, HM; Designed the experiments: MY, DG, AK; Performed the experiments:MY; Analyzed the data: MY, AK; Contributed reagents/materials: AK, SB, HM; Wrote the paper: MY, AK Read, contributed to and approved the paper: MY, HM, SB, DG, AK. All authors read and approved the final manuscript.

\section{Acknowledgements}

We acknowledge financial support from the Deutsche Forschungsgemeinschaft (DFG; German Research Foundation) of the special African-German collaborative programme, "Africa Initiative", grant GL595/3-1 to AK, HM and DG) and the National Research Foundation of South Africa (NRF; GUN\#65530 to AK). We thank Wolfram Gerlich for critical reading, Waleed Mohammed for technical assistance and clinicians at IbnSina, Soba University and Khartoum Hospitals.

\section{Author details}

${ }^{1}$ Hepatitis Virus Diversity Research Programme, Department of Internal Medicine, Faculty of Health Sciences, University of Witwatersrand, 7 York Road, Parktown, Johannesburg 2193, South Africa. ${ }^{2}$ Department of Medicine, Faculty of Medicine, University of Khartoum, Khartoum, Sudan. ${ }^{3}$ Institute of Endemic Diseases, University of Khartoum, Khartoum, Sudan. ${ }^{4}$ Institute of Medical Virology, National Reference Centre of Hepatitis B and D, Justus Liebig-University of Giessen, Giessen, Germany.

Received: 5 February 2013 Accepted: 16 July 2013

Published: 18 July 2013

\section{References}

1. WHO: Hepatitis B virus Fact sheet $N^{\circ}$ 204. 2012. http://www.who.int/ mediacentre/factsheets/fs204/en/. Accessed January 2013.

2. Kramvis A, Kew MC: Epidemiology of hepatitis B virus in Africa, its genotypes and clinical associations of genotypes. Hepatol Res 2007, 37(s1):S9-S19.

3. Mudawi HMY: Epidemiology of viral hepatitis in Sudan. Clin Exp Gastroenterol 2008, 1:9-13.

4. Mudawi HM, Smith HM, Rahoud SA, Fletcher IA, Saeed OK, Fedail SS: Prevalence of hepatitis B virus infection in the Gezira state of central Sudan. Saudi J Gastroenterol 2007, 13(2):81-83.

5. McCarthy MC, El-Tigani A, Khalid IO, Hyams KC: Hepatitis B and C in Juba, southern Sudan: results of a serosurvey. Trans R Soc Trop Med Hyg 1994, 88(5):534-536 
6. McCarthy MC, Hyams KC, el-Tigani el-Hag A, el-Dabi MA, el-Sadig el-Tayeb M, Khalid IO, George JF, Constantine NT, Woody JN: HIV-1 and hepatitis B transmission in Sudan. AIDS 1989, 3(11):725-729.

7. Mudawi HMY, Yousif BA: Fulminant hepatic failure in an African setting: Etiology, clinical course, and predictors of mortality. Dig Dis Sci 2007, 52:3266-3269.

8. Mahgoub S, Candotti D, El-Ekiaby M, Allain JP: Hepatitis B virus (HBV) infection and recombination between HBV genotypes $D$ and $E$ in asymptomatic blood donors from Khartoum Sudan. J Clin Microbio/ 2011, 49(1):298-306

9. Kramvis A, Kew M, Francois G: Hepatitis B virus genotypes. Vaccine 2005, 23(19):2409-2423.

10. Norder H, Courouce AM, Coursaget P, Echevarria JM, Lee SD, Mushahwar IK, Robertson BH, Locarnini S, Magnius LO: Genetic diversity of hepatitis B virus strains derived worldwide: genotypes, subgenotypes, and $\mathrm{HBsAg}$ subtypes. Intervirology 2004, 47(6):289-309.

11. Yu H, Yuan Q, Ge SX, Wang HY, Zhang YL, Chen QR, Zhang J, Chen PJ, Xia NS: Molecular and phylogenetic analyses suggest an additional hepatitis B virus genotype "I". PLoS One 2010, 5(2):e9297.

12. Tatematsu K, Tanaka Y, Kurbanov F, Sugauchi F, Mano S, Maeshiro T, Nakayoshi T, Wakuta M, Miyakawa Y, Mizokami M: A genetic variant of hepatitis $B$ virus divergent from known human and ape genotypes isolated from a Japanese patient and provisionally assigned to new genotype J. J Virol 2009, 83(20):10538-10547.

13. Saudy N, Sugauchi F, Tanaka Y, Suzuki S, Aal AA, Zaid MA, Agha S, Mizokami $\mathrm{M}$ : Genotypes and phylogenetic characterization of hepatitis $B$ and delta viruses in Egypt. J Med Virol 2003, 70(4):529-536.

14. Mulders MN, Venard V, Njayou M, Edorh AP, Bola Oyefolu AO, Kehinde MO, Muyembe Tamfum JJ, Nebie YK, Maiga I, Ammerlaan W, et al: Low genetic diversity despite hyperendemicity of hepatitis $B$ virus genotype $E$ throughout West Africa. J Infect Dis 2004, 190(2):400-408.

15. Mwangi J, Nganga Z, Songok E, Kinyua J, Lagat N, Muriuki J, Lihana R, Khamadi S, Osman S, Lwembe R, et al: Molecular genetic diversity of hepatitis B virus in Kenya. Intervirology 2008, 51(6):417-421.

16. Usuda S, Okamoto H, Tanaka T, Kidd-Ljunggren K, Holland PV, Miyakawa Y, Mayumi M: Differentiation of hepatitis $B$ virus genotypes $D$ and $E$ by ELISA using monoclonal antibodies to epitopes on the preS2-region product. J Virol Methods 2000, 87(1-2):81-89.

17. Hannoun C, Soderstrom A, Norkrans G, Lindh M: Phylogeny of African complete genomes reveals a West African genotype A subtype of hepatitis B virus and relatedness between Somali and Asian A1 sequences. J Gen Virol 2005, 86(Pt 8):2163-2167.

18. Kramvis A, Kew MC: Relationship of genotypes of hepatitis B virus to mutations, disease progression and response to antiviral therapy. J Viral Hepat 2005, 12(5):456-464

19. Kao JH, Chen PJ, Lai MY, Chen DS: Genotypes and clinical phenotypes of hepatitis B virus in patients with chronic hepatitis B virus infection. J Clin Microbiol 2002, 40(4):1207-1209.

20. Mohsni E: HBV and HCV Contorl in the WHO Eastern Mediterranean Region (WHO EMR). Viral Hepatitis 2010, 18(2):26-27.

21. Papatheodoridis GV, Manolakopoulos S, Liaw YF, Lok A: Follow-up and indications for liver biopsy in $\mathrm{HBeAg}$-negative chronic hepatitis B virus infection with persistently normal ALT: a systematic review. J Hepatol 2012, 57(1):196-202.

22. Weinberger KM, Wiedenmann E, Bohm S, Jilg W: Sensitive and accurate quantitation of hepatitis $B$ virus DNA using a kinetic fluorescence detection system (TaqMan PCR). J Virol Methods 2000, 85(1-2):75-82.

23. Firnhaber C, Viana R, Reyneke A, Schultze D, Malope B, Maskew M, DiBisceglie A, MacPhail P, Sanne I, Kew M: Occult hepatitis B virus infection in patients with isolated core antibody and HIV co-infection in an urban clinic in Johannesburg South Africa. Int J Infect Dis 2009, 13(4):488-492.

24. Firnhaber C, Chen CY, Evans D, Maskew M, Schulz D, Reyneke A, Kramvis $A$ : Prevalence of hepatitis $B$ virus (HBV) co-infection in HBV serologically-negative South African HIV patients and retrospective evaluation of the clinical course of mono- and co-infection. Int J Infect Dis 2012, 16(4):e268-e272.

25. Bell TG, Makondo E, Martinson NA, Kramvis A: Hepatitis B virus infection in human immunodeficiency virus infected southern African adults: occult or overt-that is the question. PLoS One 2012, 7(10):e45750.

26. Takahashi K, Aoyama K, Ohno N, Iwata K, Akahane Y, Baba K, Yoshizawa H, Mishiro S: The precore/core promoter mutant (T1762A1764) of hepatitis
B virus: clinical significance and an easy method for detection. J Gen Virol 1995, 76(Pt 12):3159-3164.

27. Vermeulen M, Dickens C, Lelie N, Walker E, Coleman C, Keyter M, Reddy R, Crookes $R$, Kramvis A: Hepatitis B virus transmission by blood transfusion during 4 years of individual-donation nucleic acid testing in South Africa: estimated and observed window period risk. Transfusion 2012, 52:880-892.

28. Kew MC, Kramvis A, Yu MC, Arakawa K, Hodkinson J: Increased hepatocarcinogenic potential of hepatitis B virus genotype A in Bantuspeaking sub-saharan Africans. J Med Virol 2005, 75(4):513-521.

29. Lindh M, Andersson AS, Gusdal A: Genotypes, nt 1858 variants, and geographic origin of hepatitis B virus-large-scale analysis using a new genotyping method. J Infect Dis 1997, 175(6):1285-1293.

30. Gunther S, Li BC, Miska S, Kruger DH, Meisel H, Will H: A novel method for efficient amplification of whole hepatitis $B$ virus genomes permits rapid functional analysis and reveals deletion mutants in immunosuppressed patients. J Virol 1995, 69(9):5437-5444.

31. Makondo E, Bell TG, Kramvis A: Genotyping and Molecular Characterization of Hepatitis B Virus from Human Immunodeficiency Virus-Infected Individuals in Southern Africa. PLoS One 2012, 7(9):e46345. doi:46310.41371/journal.pone.0046345

32. Bell TG, Kramvis A: Fragment merger: an online tool to merge overlapping long sequence fragments. Viruses 2013, 5(3):824-833.

33. Yousif M, Kramvis A: Genotype D of hepatitis $B$ virus and its subgenotypes: An update. Hepatol Res 2013, 43(4):355-364

34. Gulube Z, Chirara M, Kew M, Tanaka Y, Mizokami M, Kramvis A: Molecular characterization of hepatitis B virus isolates from Zimbabwean blood donors. J Med Virol 2011, 83(2):235-244.

35. Lole KS, Bollinger RC, Paranjape RS, Gadkari D, Kulkarni SS, Novak NG, Ingersoll R, Sheppard HW, Ray SC: Full-length human immunodeficiency virus type 1 genomes from subtype C-infected seroconverters in India, with evidence of intersubtype recombination. J Virol 1999, 73(1):152-160.

36. Bell TG, Kramvis A: Mutation Reporter Tool: An online tool to interrogate loci of interest, with its utility demonstrated using hepatitis $B$ virus. Virol J 2013, 10(1):62. doi:10.1186/1743-422X-10-62.

37. Liaw Y-F, Chien R-N, Yeh C-T, Tsai S-L, Chu C-M: Acute exacerbation and hepatitis B virus clearance after emergence of YMDD motif mutation during lamivudine therapy. Hepatology 1999, 30(2):567-572.

38. Rehermann B, Nascimbeni M: Immunology of hepatitis B virus and hepatitis C virus infection. Nat Rev Immunol 2005, 5(3):215-229.

39. Liu TT, Fang $Y$, Xiong $H$, Chen TY, Ni ZP, Luo JF, Zhao NQ, Shen XZ: A casecontrol study of the relationship between hepatitis B virus DNA level and risk of hepatocellular carcinoma in Qidong China. World J Gastroenterol 2008, 14(19):3059-3063.

40. Abdou Chekaraou M, Brichler S, Mansour W, Le-Gal F, Garba A, Deny P, Gordien E: A novel hepatitis B virus (HBV) subgenotype D (D8) strain, resulting from recombination between genotypes $D$ and $E$, is circulating in Niger along with HBV/E strains. J Gen Virol 2010, 91(Pt 6):1609-1620.

41. Kramvis A, Arakawa K, Yu MC, Nogueira R, Stram DO, Kew MC: Relationship of serological subtype, basic core promoter and precore mutations to genotypes/subgenotypes of hepatitis B virus. J Med Viro/ 2008, 80(1):27-46.

42. Kramvis A, Paraskevis D: Subgenotype A1 of Hepatitis B Virus - Tracing Human Migrations in and out of Africa. Antivir Ther 2013, 18(3 Pt B):513-521.

43. Milich D, Liang TJ: Exploring the biological basis of hepatitis $B$ e antigen in hepatitis B virus infection. Hepatology 2003, 38(5):1075-1086.

44. Carman WF, Jacyna MR, Hadziyannis S, Karayiannis P, McGarvey MJ, Makris A, Thomas HC: Mutation preventing formation of hepatitis $B$ e antigen in patients with chronic hepatitis B infection. Lancet 1989, 2(8663):588-591.

45. Li JS, Tong SP, Wen YM, Vitvitski L, Zhang Q, Trepo C: Hepatitis B virus genotype $A$ rarely circulates as an $\mathrm{HBe}$-minus mutant: possible contribution of a single nucleotide in the precore region. J Virol 1993, 67(9):5402-5410.

46. Lok AS, Akarca $U$, Greene $S$ : Mutations in the pre-core region of hepatitis $B$ virus serve to enhance the stability of the secondary structure of the pre-genome encapsidation signal. Proc Natl Acad Sci USA 1994 91(9):4077-4081.

47. Ahn SH, Kramvis A, Kawai S, Spangenberg HC, Li J, Kimbi G, Kew M, Wands $J$, Tong S: Sequence variation upstream of precore translation initiation codon reduces hepatitis $B$ virus e antigen production. Gastroenterology 2003, 125(5):1370-1378.

48. Garmiri P, Loua A, Haba N, Candotti D, Allain JP: Deletions and recombinations in the core region of hepatitis $B$ virus genotype $E$ strains 
from asymptomatic blood donors in Guinea, west Africa. J Gen Virol 2009, 90(Pt 10):2442-2451.

49. Chen BF, Liu CJ, Jow GM, Chen PJ, Kao JH, Chen DS: High Prevalence and Mapping of Pre-S Deletion in Hepatitis B Virus Carriers With Progressive Liver Diseases. Gastroenterology 2006, 130(4):1153-1168.

50. Mun H-S, Lee S-A, Kim H, Hwang E-S, Kook Y-H, Kim B-J: Novel F141L PreS2 Mutation in Hepatitis B Virus Increases the Risk of Hepatocellular Carcinoma in Patients with Chronic Genotype C Infections. J Virol 2011, 85(1):123-132.

51. Biswas A, Panigrahi R, Banerjee A, Pal M, De BK, Chakrabarti S, Chakravarty R: Differential pattern of pre-S mutations/deletions and its association with hepatitis B virus genotypes in Eastern India. Infect Genet Evol 2012, 12(2):384-391.

52. Carman WF: The clinical significance of surface antigen variants of hepatitis B virus. J Viral Hepat 1997, 4(Suppl 1):11-20.

53. Dupouey J, Gerolami R, Solas C, Colson P: Hepatitis B virus variant with the a194t substitution within reverse transcriptase before and under adefovir and tenofovir therapy. Clinics and Research in Hepatology and Gastroenterology 2012, 36(2):e26-e28.

doi:10.1186/1471-2334-13-328

Cite this article as: Yousif et al:: Molecular characterization of hepatitis B virus in liver disease patients and asymptomatic carriers of the virus in Sudan. BMC Infectious Diseases 2013 13:328.

\section{Submit your next manuscript to BioMed Central and take full advantage of:}

- Convenient online submission

- Thorough peer review

- No space constraints or color figure charges

- Immediate publication on acceptance

- Inclusion in PubMed, CAS, Scopus and Google Scholar

- Research which is freely available for redistribution 